\title{
SUBSIDING OF AGRICULTURE OF UKRAINE: MAIN DIRECTIONS, PROBLEMS AND PROSPECTS
}

\author{
TETIANA KULAKOVSKA
}

\begin{abstract}
The article analyses the main forms of state support for agricultural producers of Ukraine for the period from 1991 to 2017 for the main types of agricultural products. Two areas of support for producers of livestock and crop products are considered: supporting the market price of products and subsidies from the state budget. The main problems of state support for the development of agriculture are highlighted, among which there is an imbalance in the support of commodity producers through direct subsidies and through the support of market prices by indirect regulatory methods. The paper considers the main directions of subsidies to the EU countries and develops proposals to improve the agricultural policy of Ukraine.
\end{abstract}

Keywords: subsidies, agriculture, market price support, direct subsidies.

JEL codes: Q18, O13, P23.

\section{Introduction}

Improving the competitiveness of agricultural products and the level of food selfsufficiency is influenced by the state policy of supporting the agricultural producer.

The study of state support measures for agricultural producers and their sources of funding, changes in the volume and structure and the long-term dynamics make it possible to identify general trends, evaluate the effectiveness of implemented measures, identify shortcomings in government policy to support the agricultural sector and develop proposals for improving the policy, taking into account all restrictions of the external economic environment. To study the sources and methods of state 
support for agricultural producers for individual types of products the author applied a methodology developed by the Organization for Economic Cooperation and Development (OECD). This technique divides the price support of producers (through the support of market prices) and subsidies from the budget for a specific type of product.

\section{Material and method}

Market prices are supported by foreign trade regulation through import quotas and duties, export subsidies and so on. This is an indirect form of producer support.

A second source of financial support for agricultural producers are subsidies from the budget for a specific type of product.

In accordance with the Agreement on Subsidies and Countervailing Measures (ASCM) adopted at the Tokyo Round (1979), the subsidy should be considered as the distribution of funds by the state, creating benefits, directly or through a third party.

Such definition includes actions such as the provision by the state of goods and services, the state's refusal of income, which otherwise could be received by the state budget, state support for prices or revenues.

Depending on the purpose of the subsidy, it is divided into prohibited subsidies, subsidies giving grounds for the application of measures and those to which compensatory measures do not apply.

Prohibited types of subsidies include subsidies, which are awarded on the condition of using exported or domestic goods instead of import (export subsidies).

The category of subsidies that do not lead to the application of measures (the corresponding compensation fee) includes subsidies for research and development, assistance to regions with adverse conditions, as well as certain types of support aimed at bringing production facilities in line with environmental protection measures, legislation and regulations.

The categories of subsidies that give rise to the application of measures include measures that have a distorting effect on trade, affect production. Such subsidies include subsidies for livestock and crop production, subsidies for livestock breeding, subsidies for the production of elite seeds (for sold seeds), subsidies for feed, reimbursement of part of the cost of purchasing mineral fertilizers and chemical plant protection products, reimbursement of part of energy costs, reimbursement of part of the cost of improving soil fertility, compensation for the cost of equipment purchased in order to sale agricultural products, the cost of repairs and current maintenance of land reclamation systems, leasing fund expenses, expenses for the creation of seasonal stocks of spare parts and material and technical resources, capital investments for production purposes, except for capital expenditures on land reclamation and water management, price support (compensation for the difference between the purchasing and market prices of agricultural products/services) at below market prices, purchase of goods (services) from the manufacturer at prices above market prices, preferential loans to agricultural producers from the state and local budgets, including write-offs and debt rollover, the benefits for transportation of agricultural products. The use of such subsidies should be limited and balanced with the requirements of international organizations (WTO). 


\section{Results}

Support for agricultural producers in Ukraine was carried out through the mechanism of subsidizing and supporting the market price for the main types of crop production (barley, corn, oats, wheat, rye, sunflower, etc.) and animal husbandry (beef, pork, poultry, dairy products, eggs, etc.).

A study of measures to support wheat producers showed that the indicator of market price support had the greatest impact. During the years between 1991 and 2017 (except for 1991, 1994, 1997-1998, 2000, and 2003) it had a negative value, which indicates lower domestic prices for wheat compared to world prices. The largest gap between the domestic and world price for wheat was obtained in 2008, it was significantly reduced in 2009 and 2010 after Ukraine joined the WTO. But already in 2011, this gap increased almost 6 times, and in 2014 - 13 times. Budget payments that should compensate for the loss of producers, unfortunately, did not fulfil this function. Payments were made in the form of payments per 1 ton of products: in 1991 (UAH 742 million), 1992 (UAH 0.13 million), 1996 (UAH 0.1 million), 1999 (UAH 0.3 million), 2000 (UAH 2 million) and 2001 (UAH 9 million), and from 2006 to 2008 - in the form of payments per 1 hectare of sown area (about UAH 430 million annually). In 2004, 2005 and 2006, the support of manufacturers was also carried out in the form of subsidizing interest rates on loans (UAH 20 million, UAH 22 million, UAH 12 million, respectively).

In cases of world prices exceeding domestic prices and insignificant compensation for producer losses, it should be noted that producers are taxed in excess.

Similar situation with the support of producers of barley. Payments from the budget of 1 ton were made in 2000 (UAH 1 million) and 4 times more in 2001 (UAH 4 million). From 2006 (UAH 278 million) to 2008 (UAH 152 million), payments were made from 1 ha of sown area. Interest rate subsidies for the study period occurred only once in 2004 (UAH 7 million).

As for the producers of rye and oats, there is a similar trend: the indicator of support for the market price up to 2006 (oats) and 2007 (rye) had a positive value, which indicates that domestic prices exceed world prices. Support for producers of rye and oats for a specified period was carried out at the expense of consumer transfers (i.e. the consumer must buy these goods at inflated prices). Payments from the budget for oats were made per 1 hectare only in 2006 (UAH 24 million) and 2008 (UAH 21 million). Budget subsidies for rye are made in the form of payments per 1 ton in 2001 (UAH 1 million), and from 2006 (UAH 29 million) to 2008 (UAH 32 million) - in the form of payments per 1 hectare of sown areas. In 2004 (UAH 1 million) and 2005 (UAH 3 million), interest rates on loans were subsidized. It should be noted that budgetary payments were made in those years when domestic prices for oats and rye already exceeded world prices. Only in 2006 and 2008 for oats and 2004 for rye was an attempt to partially compensate for the losses of producers. 


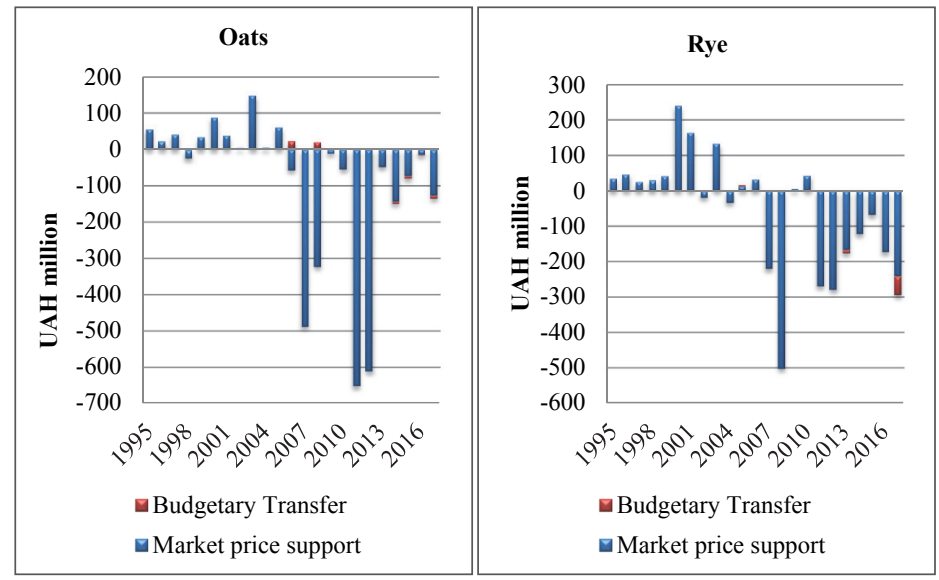

Fig. 1. Dynamics of oats and rye producers support during 1995-2017.

Source: Agricultural support. Organization for economic cooperation and development. Retrieved from: http:// www.oecd.org/tad/agricultural-policies/producerand consumersupport estimatesdatabase.htm\# browsers.

Similar trends are observed in the support of producers of corn and sunflower: the indicator of support for the market price had a negative value with the exception of three years (for corn - 1999, 2003 and 2006; for sunflower - 2001, 2007 and 2009). This indicates excessive taxation of producers. Payments from the budget are so small and unsystematic that they do not compensate for the losses of producers. Payments from the budget for 1 ton of sunflower were made only in 2001 (UAH 1 million) and 2002 (UAH 2 million). There were no other payments from the budget for this crop. In 2001, budget support for corn producers was in the form of subsidies per 1 ton (UAH 2 million), in 2004 - in the form of subsidizing interest rates on loans (UAH 6 million) and in the form of payments per 1 hectare of sown area in 2006 (UAH 85 million) and 2008 (UAH 98 million).

The situation is quite different with the support of sugar beet producers. From 1996 to 2012, the market price support indicator received a positive value. This means that domestic prices were higher than limit prices, which indicates that the industry has been subsidized. In addition, the development of the industry was supported by direct payments from the budget for 1 ton in 2000 (UAH 1 million), 2001 (UAH 2 million) and 2010 (UAH 198 million).

It should be noted that the main burden of supporting the development of crop production has been transferred to consumers, who have to pay the price for agricultural products in the domestic market more than for the world price. Budget transfers are chaotic, inconsistent, carried out according to current needs, and not systematic. The budget payments for most types of crop production are so insignificant that they cannot compensate for the losses of producers. 


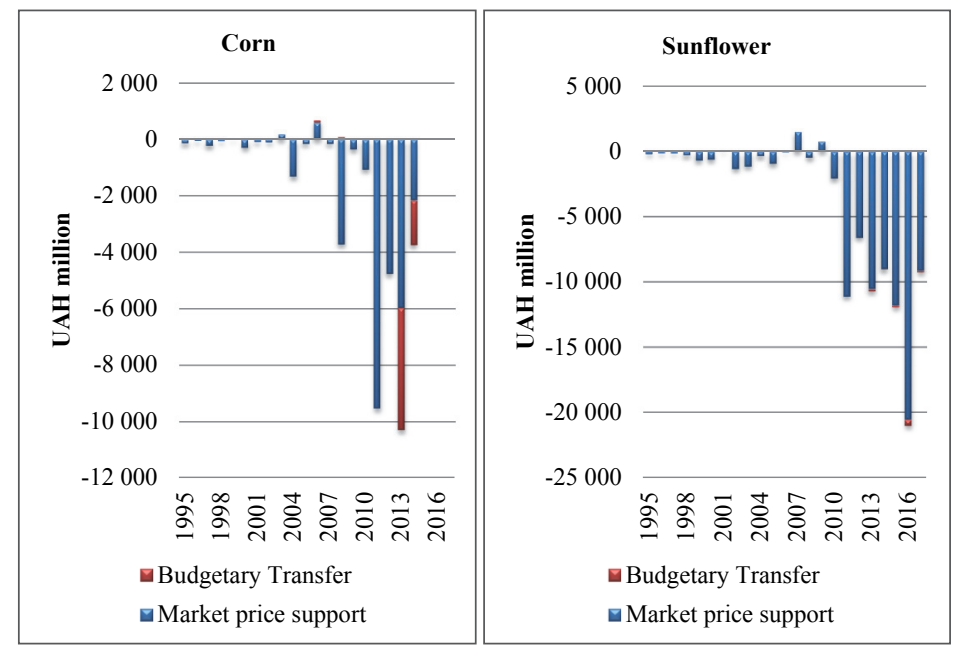

Fig. 2. Dynamics of corn and sunflower producers support during 1995-2017.

Source as in Figure 1.

The situation is somewhat different in the livestock market. So, beef producers have significant support from the state in the form of budget subsidies. Payments per 1 ton of products from 1997 to 2008 increased almost 100 times (from UAH 11 million to UAH 1018 million), and further there was a reduction in payments. In addition, budgetary payments were made for the livestock of animals: from 2003 to 2012, the amount of support increased more than 300 times (from UAH 1 million to UAH 366 million). Support for the market price for beef has a wave-like dynamics, changing from a negative to positive value.

The indicator of market price support for milk during almost the entire study period (except for 2005, 2006, 2008 and 2009) was negative, which indicates a significant excess of world prices for milk over domestic prices. The greatest deviation in the price of milk is observed in 2007. Milk producers do not receive the income that they could have if milk was sold on the world market. Therefore, the state provided for budgetary payments in the form of subsidies for 1 ton of products, which were carried out from 1997 to 2012. The amount of budget payments increased 90 times (from UAH 20 million to UAH 1763 million), followed by a sharp decline in 2011 (UAH 6 million). The state pays the greatest attention to the development of meat and dairy livestock production.

On the pork market until 2005, domestic prices were lower than world prices (with the exception of 1998 and 2001). During this period, there has excessive taxation of producers. At the same time, budget payments for 1 ton of products, which began to be paid out in 1997 (UAH 13 million), did not allow to compensate for lost income. Since 2005, the indicator of support for the market price of pork has had a positive value, which indicates that the production has been subsidized by consumers who had to pay a price higher than the world price. In the same period, budgetary payments per 1 ton continue. 


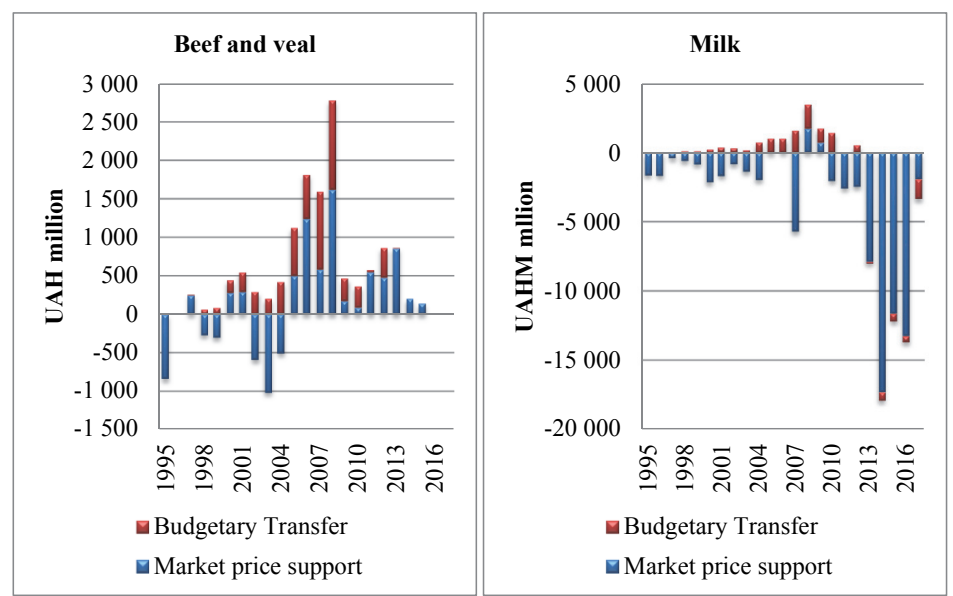

Fig. 3. Dynamics of beef and milk producers support during 1995-2017.

Source as in Figure 1.

The market for poultry meat and eggs shows a very different trend. Domestic prices for poultry meat are higher than world ones, so domestic consumers have to pay a higher price for their products, while there is a steady tendency to increase the gap between domestic and world prices. In addition to indirect subsidizing of the production by consumers, there is direct support for the development of the industry at the expense of budget payments for 1 ton of products: for the period from 1997 (UAH 4 million) to 2008 (UAH 550 million), the amount increased almost 140 times, and then there was a sharp reduction in budget payments. On the egg market, the tendency of domestic prices to exceed world prices prevails, the burden of subsidies has been transferred to the consumer.

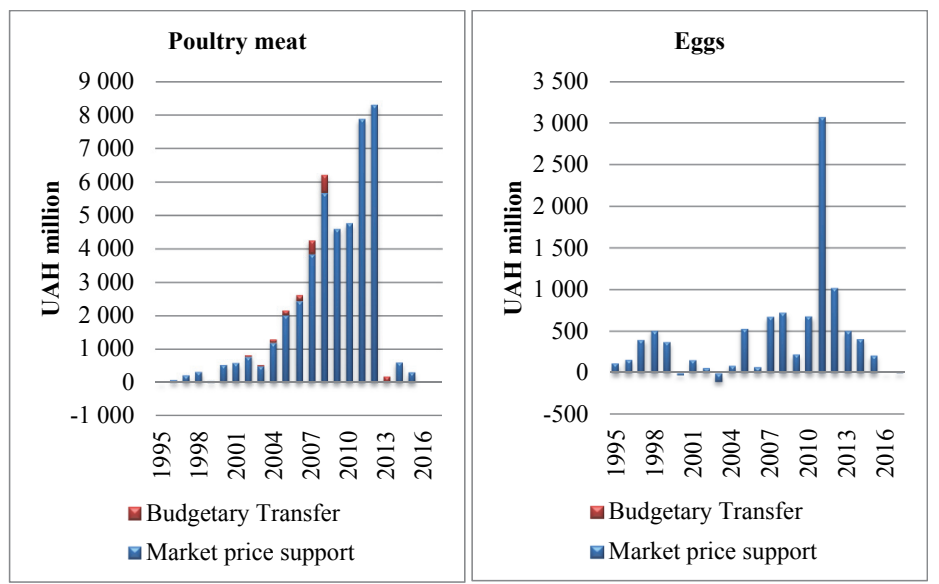

Fig. 4. Dynamics of poultry meat and eggs producers support during 1995-2017.

Source as in Figure 1. 


\section{Conclusions}

In general, three trends stand out in livestock production markets: the first is subsidized support for beef and milk producers, the second is indirect subsidization of poultry meat and eggs by consumers, and the third is uncertainty in the policy of supporting pork producers.

It should be noted that in the market of crop and livestock products, the main factor influencing the performance of agricultural producers is to support market prices. This support is mainly provided by the consumers of products, who are forced to pay a higher price than for similar products on the world market.

Meat and dairy cattle industry should be distinguished as one of the most subsidized industries. This is due to a significant deterioration in the state of the industry compared to 1991, a reduction in the number of cattle and the like.

Two mechanisms to support agricultural producers (support for market prices and budget payments) are not consistent with each other at all. In those years when market price support is positive, significant payments are made from the budget, which reinforces (when it is necessary to restrain) development. In those years when support for the market price turns out to be negative, the state either does not compensate for the loss of producers at all, or does not provide them in sufficient quantities.

Significant changes in measures to support agricultural producers associated with Ukraine's accession to the WTO. Ukraine significantly reduced budgetary payments to producers and switched (for most products) from subsidizing 1 ton to subsidizing for 1 hectare of sown area. It should be noted that in the EU in general they refused direct payments to agricultural producers for a specific product. Today, it is just a payment per farm, which does not depend on the type of activity (growing grain or cattle).

As a result of the research, it was found that the main problems of state regulation of the development of the agricultural sector of Ukraine are: 1) lack of consistency in the application of appropriate levels of state regulation; 2) lack of comprehensiveness in the direction of supporting the development of the agrarian sector (agricultural producers, processors and consumers); 3) lack of coherence of the state's actions to support and regulate the development of the agricultural sector with periods of economic development, and the like.

All the identified shortcomings of the agrarian policy, which was carried out throughout the years of Ukraine's independence, made it possible to propose new conceptual approaches to the state policy of regulation and support for the development of the agricultural sector of Ukraine. Among the most weighty principles of state agrarian policy are the following: 1) it is necessary to deviate from the application of regulatory measures in the agrarian sector to measures that are aimed at coordinating actions on the agri-food market, taking into account the entire chain of creation of the added value of the final product; 2 ) it is necessary to move away from the outdated system of uncontrolled support of the agricultural sector, based on the specific features of agriculture to the general principles of regulating 
the development of the economy (including the agri-food sector), taking into account the cyclical mechanism of development of the economic system; 3 ) the influence of state regulation of the agri-food sector (tax, price, customs, etc.) among themselves should be coordinated and should be monitored to balance the load in supporting the development of the agri-food sector between the state and consumers of final products. 


\section{References}

Agricultural policies in OECD and emerging economies: Monitoring and Evaluation 2017. Retrieved from: www.oecd.org/tad/agricultural-policies/AgMon_2017 Ukraine_RUS.pdf

Agricultural support. Organization for economic cooperation and development. Retrieved from: http://www.oecd.org/tad/agricultural-policies/producerand consumersupport estimatesdatabase.htm\# browsers.

Methodology for the measurement of support and use in policy evaluation. Organization for economic co-operation and development. Retrieved from: http://www.oecd.org/dataoecd/36/47/1937457.pdf

Producer and Consumer Support Estimates database. Organization for economic cooperation and development. Retrieved from: http://www.oecd.org/countries /ukraine/producerandconsumersupportestimatesdatabase.htm.

Ukraine // Agricultural Policy Monitoring and Evaluation, 2018. 


\title{
SUBSYDIOWANIE ROLNICTWA UKRAINY: GŁÓWNE KIERUNKI, PROBLEMY I PERSPEKTYWY
}

\begin{abstract}
Abstrakt
Artykut analizuje główne formy wsparcia państwa dla producentów rolnych Ukrainy w okresie od 1991 do 2017 roku dla glównych rodzajów produktów rolnych. Rozważane sa dwa obszary wsparcia dla producentów produktów pochodzenia zwierzęcego i roślinnego: wsparcie cen rynkowych produktów i dotacje $z$ budżetu państwa. Podkréslono główne problemy wsparcia państwa na rzecz rozwoju rolnictwa, w tym brak spójności we wsparciu producentów surowców poprzez dopłaty bezpośrednie $i$ wsparciu cen rynkowych za pomoca pośrednich metod regulacyjnych. Artykuł dotyczy głównych kierunków wsparcia $w$ krajach UE i przedstawia propozycje poprawy polityki rolnej Ukrainy.
\end{abstract}

Słowa kluczowe: dotacje, rolnictwo, wsparcie cen rynkowych, dopłaty bezpośrednie.

Accepted for print: 11.12.2019.

Unless stated otherwise all the materials on the website are available under the Creative Commons Attribution 4.0 International license.

Some rights reserved to the Institute of Agricultural and Food Economics - National Research Institute.

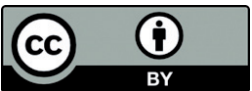

